\title{
Papposphaera obpyramidalis (Haptophyta, Papposphaeraceae): New findings from both Polar Regions
}

\author{
Thomsen, Helge Abildhauge; Egge, Jorun Karin; Heldal, Mikal
}

\section{Published in:}

Revue de Micropaleontologie

Link to article, DOI:

10.1016/j.revmic.2016.03.005

Publication date:

2016

Document Version

Peer reviewed version

Link back to DTU Orbit

Citation (APA):

Thomsen, H. A., Egge, J. K., \& Heldal, M. (2016). Papposphaera obpyramidalis (Haptophyta,

Papposphaeraceae): New findings from both Polar Regions. Revue de Micropaleontologie, 59(3), 267-273. https://doi.org/10.1016/j.revmic.2016.03.005

\section{General rights}

Copyright and moral rights for the publications made accessible in the public portal are retained by the authors and/or other copyright owners and it is a condition of accessing publications that users recognise and abide by the legal requirements associated with these rights.

- Users may download and print one copy of any publication from the public portal for the purpose of private study or research.

- You may not further distribute the material or use it for any profit-making activity or commercial gain

- You may freely distribute the URL identifying the publication in the public portal 
1 Papposphaera obpyramidalis (Haptophyta, Papposphaeraceae): New findings from both Polar

2 Regions

3

4 Papposphaera obpyramidalis (Haptophyta, Papposphaeraceae): Nouvelles découvertes provenant 5 des deux régions polaires.

6

$7 \quad$ Helge Abildhauge Thomsen $^{\mathrm{a}}$, Jorun Karin Egge ${ }^{\mathrm{b}}$, Mikal Heldal ${ }^{\mathrm{b}}$

8 National Institute of Aquatic Resources (DTU Aqua), Technical University of Denmark,

9 Charlottenlund, Denmark;

* Corresponding author

E-mail address: hat@aqua.dtu.dk (H. Thomsen) 


\section{Abstract}

Papposphaera obpyramidalis is reinvestigated based on additional high latitude sampling from the southern hemisphere. The material used here comprises better preserved TEM material including several cells with complete flagellation, as well as LM of living material. The reexamination basically confirms the findings that were part of the species description but also adds details on e.g. nutritional mode and the presence of an underlayer of unmineralized scales. Papposphaera obpyramidalis has hitherto been considered confined to Antarctic waters. However, here we present also findings of the species from Arctic realms based on recent SEM surveys from the Svalbard region, indicating a bipolar distribution.

Keywords: Coccolithophore, coccolithophorid, Papposphaera, P. obpyramidalis, polar regions, electron microscopy

\section{Résumé}

Papposphaera obpyramidalis est de nouveau étudiée à partir des échantillons provenant des hautes latitudes de l’hémisphère Sud. Le matériel utilisé ici comprend du materiel MET mieux préservé avec notamment plusieurs cellules à flagellations complètes, ainsi que du LM de matériaux vivants. Le réexamen confirme les résultats qui faisaient déjà partie de la description de l'espèce, mais apporte aussi des détails, comme par exemple sur le mode nutritionnel et la présence d'une sous-couche d'écailles non minéralisées. Papposphaera obpyramidalis était jusqu'à présent considérée restreinte aux eaux de l'océan Austral. Cependant, nous présentons également ici des résultats de l'espèce provenant des eaux arctiques, basé sur des observations récentes au MEB de matériel provenant de Svalbard, indiquant ainsi une distribution bipolaire de l'espèce.

Mots clés : Coccolithophore, coccolithophoridés, Papposphaera, P. obpyramidalis, régions polaires, microscopie électronique 
40 Abbreviations: TEM - transmission electron microscope; SEM - scanning electron microscope;

41 LM - light microscope; AMERIEZ, EPOS, ANT X/3 - acronyms for Antarctic cruises (see 42 Materials and Methods) 


\section{Introduction}

Papposphaera obpyramidalis Thomsen in Thomsen et. al. 1988 was described based on the finding of four coccospheres among the Weddell Sea AMERIEZ material. The main feature of this species, i.e. the large calyces each formed by four triangular plates, renders this taxon easily recognizable and it has accordingly been observed in a number of subsequent TEM and SEM based surveys of coccolithophores along transects and station grids leading into the Antarctic region. Papposphaera obpyramidalis is thus established as an iconographic representative of the Antarctic community of lightly calcified coccolithophores. We present here further details, e.g. the collapsed nature of the pyramids and the presence of underlayer scales, on P. obpyramidalis based on light microscopy and transmission electron microscopy of material collected during the EPOS and ANT X/3 Antarctic cruises.

We have until recently considered $P$. obpyramidalis as being confined to the southern hemisphere. The reasoning behind this is that whilst there are frequent recordings from Antarctic waters, the taxon is absent from species lists from the large scale Arctic TEM nannoflagellate surveys conducted over the last decades. However, bipolarity within $P$. obpyramidalis has now become an issue in as much as this organism has been found on some occasions during recent SEM surveys of material mostly from the Svalbard region. We will below illustrate these findings and make some initial comparisons of the two subsets of material.

The redescription and overall update on current knowledge with reference to P. obpyramidalis is part of an ongoing effort to establish a coherent overview of the community of lightly calcified coccolithophores from Polar Regions. The first paper in this series targeted the genus Wigwamma Manton, Sutherland and Oates 1977 (Thomsen et. al., 2013), and we are currently in turn dealing with species of Papposphaera (Thomsen and Egge, 2016; Thomsen and Østergaard, 2016; Thomsen et. al., 2015a,b; Thomsen et al., 2016). 


\section{Materials and methods}

The Antarctic material for transmission electron microscopy originates from the R/V ‘Melville’ AMERIEZ cruise (March 1986), the R/V ‘Polarstern’ ANT VII/3 ‘EPOS II’ cruise (Nov. 1988 - Jan. 1989) and the R/V 'Polarstern’ ANT X/3 ‘Herbst im Eis’ cruise (April-May 1992), with all cruises occupying stations in the Weddell Sea region (Fig. 1A). The Arctic material derives from an ongoing sampling programme collecting material for scanning electron microscopical analysis that has been conducted since 2012 in the fjord systems of Svalbard and also at other Arctic sites. table in a cold container thus being operated at ambient sea temperatures. A Wild MPS-55 photographic unit and a flash system were used to optimize photography and to further reduce any vibrations generated by the ship.

Table 1 summarizes collection specific data for the material actually used here for illustration purposes.

The protocol for processing water samples for transmission electron microscopy (TEM) was similar on all sampling occasions (see Moestrup and Thomsen, 1980). The nannoplankton community was concentrated for further processing by means of either centrifugation of a prefiltered (usually $20 \mu \mathrm{m}$ ) water sample or centrifugation of prefiltered material resuspended from an initial concentration of cells on top of e.g. a $1 \mu \mathrm{m}$ Nuclepore filter. Small droplets of cells from the resuspended final pellet of material were placed on carbon coated grids for the TEM. Cells were subsequently fixed for ca. 30 seconds in the vapour from a 1-2\% solution of $\mathrm{OsO}_{4}$. After 
91 drying the grids were carefully rinsed in distilled water in order to remove salt crystals. Grids were 92 shadow cast with either $\mathrm{Au} / \mathrm{Pd}$ or $\mathrm{Cr}$ prior to the examination in JEOL electron microscopes 93 property of the Botanical Institute at the Univ. of Copenhagen. Material for the SEM was prepared by gentle filtration of a water sample on top of a $1.0 \mu \mathrm{m}$

95 Nuclepore filter. The formation of salt crystals that might obstruct the visibility of cells was minimized by allowing the pumping system to almost completely dry out the filter. Filters were sputter coated with gold and examined on a Zeiss Supra 55VP scanning electron microscope at the Bergen University Laboratory for Electron Microscopy. The terminology follows wherever possible Young et. al. $(1997,2003)$. 
102

\section{Observations}

\subsection{Antarctic material / light microscopy (Fig. 2E-J)}

P. obpyramidalis was abundantly present in ANT X/3 samples to the extent that it was repeatedly observed live in the light microscope. Fig. 2E-J represent images of one particular cell. When focusing through the cell different features become visible. The cell is flagellated and the haptonema is visible curled up at the front end of the cell (Fig. 2E, I, arrows). The coccoliths with their oversized calyces are clearly visible in Fig. 2G-H, J. These LM images also clearly show the size differences within the individual coccosphere with the largest and tallest coccoliths clustering around the flagellar pole. The outline of coccolith bases can be seen in Fig. 2E, I (arrows). Figure 2F focuses on the outer edge of the coccosphere and displays the most distal edges of the individual coccoliths. The short and sharp lines, that are more or less perpendicular to the longitudinal axis of the cell, are definitive proof of the fact that the calyx in this species is flattened and 2-dimensional. The species epithet was chosen based on the erroneous assumption that the four triangular blades in an undisturbed cell would form an inverted pyramidal structure.

The final feature to comment on here is the appearance of the cytoplasm. Most controversial is the fact that this cell is devoid of a chloroplast. We have observed many live cells none of which had any trace of a chloroplast, and the absence of a chloroplast has also been verified based on fluorescence microscopy. The generally accepted paradigm within coccolithophores at large is that they are photosynthetic with the occasional possibility of supplementing the carbon sequestering by mixotrophy. Polar coccolithophores, and in particular members of the Papposphaeraceae, are unique in relying exclusively on heterotrophy for their survival.

\footnotetext{
3.2 Antarctic material / transmission electron microscopy (Fig. 2A-D, K; Fig. 3A-B)
} 

$\mathrm{X} / 3$ cruises basically confirms the observations that were part of the first AMERIEZ based description of the species (Thomsen et. al., 1988). We have added images showing cells with complete flagellation and haptonema (Fig. 2A, D; Fig. 3A-B) which represents the normal appearance of $P$. obpyramidalis. The coccosphere typically measures 8-10 $\mu \mathrm{m}$ in external diameter and 4- $5 \mu \mathrm{m}$ in interior diameter. It is obvious from the complete cells shown in Fig. 1A, D that there is a pronounced difference in the size of coccoliths from one end of the cell to the other, i.e. the coccoliths are varimorphic. The proximal part of a coccolith is narrowly elliptical and measures 1.1-1.3 x 0.6-0.9 $\mu \mathrm{m}$. The coccolith rim is standard for a papposphaeracean murolith and the height varies from $0.25-0.30 \mu \mathrm{m}$. It comprises two cycles of overlapping and interlocking elements (Fig. 2K). The central area calcification is an axial cross (Fig. 2B-C, K) that leads into a central calicate spine where the stem varies in size $(0.5-1.6 \mu \mathrm{m})$ with the most long-stemmed coccoliths encircling the flagella. When measuring the size of the terminal 'pyramid' between its lateral extremes the mean value is $2.1 \pm 0.42 \mu \mathrm{m}$ (Fig. 2A) and $2.1 \pm 0.25 \mu \mathrm{m}$ (Fig. 2D) with absolute ranges from 1.7-2.6 $\mu \mathrm{m}$ (Fig. 2A) and 1.4-2.8 $\mu \mathrm{m}$ (Fig. 2D).

A high magnification of coccoliths (Fig. 2K) documents the presence in this species of organic underlayer scales each with a fine pattern of radiating and concentric threads. The dimensions of these are $0.25-0.3 \times 0.3-0.4 \mu \mathrm{m}$. It is important to mention that the presence of organic underlayer scales of this morphology is confirmed also from other micrographs, to rule out the possibility that the linkage between coccoliths and organic scales illustrated here is just fortuitous.

\subsection{Arctic material / scanning electron microscopy (Fig. 3C-D)}


The Arctic material includes coccospheres (Fig. 3C) and scatters of coccoliths (Fig. 3D) that comprise individual coccoliths which are dimensionally and morphologically very similar to those from Antarctica. The coccolith thus measures $1.26 \pm 0.13 \times 0.80 \pm 0.08 \mu \mathrm{m}$ with an overall size range of 1.1-1.5 x 0.65-0.95 $\mu \mathrm{m}$, while the maximum size span of the calyx ranges from 1.6 to $2.0 \mu \mathrm{m}$. The stem of the central process is similarly short as previously seen in Antarctic specimens. It is obvious from Fig. 3C-D that the calyx is also here a flattened 'pyramid' although damage to some of the coccoliths as part of the preparational procedure has caused some of the calyces to bend and the flattened pyramid to 'open up'.

\section{Discussion}

While the starting point here is evidence for an aplastidic condition in P. obpyramidalis it is important to emphasize that this appears to be in fact a general characteristic of the entire community of polar lightly calcified coccolithophores. We have over the last decades examined hundreds of dried cells of lightly calcified polar coccolithophores (across all genera and species) at high magnification in freshly prepared material and searched for a chloroplast using primarily epifluorescence techniques. Whereas nearby control cells, e.g. small diatom cells, always fluoresced distinctly red when excited, this was never the case for any of the lightly calcified coccolithophores. The first member of the lightly calcified coccolithophore community that was found to be non-photosynthetic was in fact Balaniger virgulosa HOL (Thomsen and Oates 1978)Thomsen and Østergaard 2014 (= Balaniger balticus Thomsen and Oates 1978). Although this was not specifically mentioned in the TEM description of this species (Thomsen and Oates, 1978), it has due to the frequent occurrence of this form in Danish coastal waters, become a regularly confirmed fact since then. The $B$. virgulosa signature when observed live is unmistakable, i.e. a heart-shaped greyish-whitish cell body with two long flagella and a somewhat shorter haptonema. While few of the lightly calcified coccolithophores can be convincingly identified in the light microscope - with 
$P$. obpyramidalis being one of the rare exceptions -the group as such has a very distinct appearance

173 due to the unique combination of the colourless cell interior, the typical haptophyte appendages

174 (flagella and haptonema) and a scaly periplast.

While it is evident to us that the polar lightly calcified coccolithophore communities are

genuinely non-photosynthetic across the entire range of genera and species, it remains to be verified whether their relatives from tropical waters share their heterotrophic life mode. Is the lack of chloroplasts in polar forms a primary feature or is it a secondary derived feature selected for due to environmental stress, e.g. prolonged periods of darkness? In order to properly address this issue cultures of one or more of these enigmatic organisms will be needed.

It is a well-established fact that species of Papposphaera and species of Turrisphaera form part of the same life cycles even though it has so far only been documented in a few cases $(P$. sagittifera/T. borealis; P. sp. nov./Turrisphaera arctica; $P$. sarion/Turrisphaera sp. nov.; see Thomsen et. al., 1991, 2016a,b) . It should be emphasized that also the generic type, $P$. lepida Tangen 1972, appears in combination cells with a species of Turrisphaera (Young et al., 2015). It is thus to be expected, based on e.g. the convincing similarity between the generic type and $P$. comparison with the diversity observed in Papposphaera. This applies to the Polar Regions and interestingly enough also to warm water habitats that have recently been found to accommodate many species of Papposphaera, but, very few species of Turrisphaera. The features available in 193 concept is perhaps in operation here. This is an issue that needs to be pursued using DNA sequencing which is the proper tool for detecting and differentiating morphologically similar species. 
When browsing through the literature on lightly calcified polar coccolithophores the question

197

198 arises whether minute unmineralized underlayer scales are to be found across the genus and species matrix according to some kind of masterplan. So far we have seen these scales in all five species of Wigwamma (i.e. W. arctica, W. annulifera, W. antarctica , W. triradiata, and W. armatura / see Thomsen et. al., 2013) and also within Calciarcus (see Thomsen and Østergaard, 2014a) which is strongly expected to share a life history with species of Wigwamma. Unmineralized underlayer scales are also a shared feature among species of Turrisphaera (i.e. T. borealis, T. polybotrys / see Manton et. al., 1976 and Thomsen, 1980a), Trigonaspis (i.e. T. diskoensis, T. minutissima, and T. melvillea / see Thomsen, 1980b and Thomsen and Østergaard, 2015), and Quaternariella (i.e. Q. obscura / see Thomsen, 1980c). It thus appears safe to conclude (based on the multiple occurrences within a number of genera) that the presence of unmineralized underlayer scales is a basic feature of at least the genera Wigwamma, Turrisphaera and Trigonaspis. The only formally described species from this cluster of genera which is not so far associated with unmineralized scales is Turrisphaera arctica, and the reason behind this is most likely a lack of adequate material to document their presence. The presence of small unmineralized underlayer scales in P. obpyramidalis (Fig. 2K) is somewhat unexpected, because this is in fact the first species of Papposphaera in which these have been found. However, it should be mentioned that such scales have also been found in a single species of Pappomonas, i.e. P. garissonii Thomsen and Østergaard 2014 (see Thomsen and Østergaard, 2014b). It is premature to conclude anything about the possible consequences of these findings. Is the presence or absence of these scales critical at the level of the circumscription of genera? - or is it merely a species characteristic? In many cases negative evidence with respect to the occurrence of these scales is not very helpful, because the species in question may be either seriously under sampled or the material available not of a quality that allows for the recognition of these scales even when using a TEM. However, when it comes to the genera Papposphaera and 
Pappomonas under sampling is generally not an issue, nor is the overall quality of the material a problem, so in these particular cases negative evidence will most likely have to be accepted as valid evidence. As indicated above we will for the time being have to leave this case open and basically proceed whenever possible to simply accumulate additional evidence on the presence or absence of these structures.

The final issue to be briefly introduced here is that of bipolarity. The general picture is here that the two poles share genera while species tend to be found in only one or the other polar region. The apparent exceptions from this general rule of thumb are Wigwamma arctica, W. annulifera, Calciarcus alaskensis 'morphotype 3’, Papposphaera sagittifera (Antarctic material yet referred to as $P$. sagittifera cfr.) and finally P. obpyramidalis as reported here. Without access to molecular data to provide the final proof of bipolarity, there is not much that can be done at this moment apart from continue to keep track on forms that potentially have a bipolar distribution.

\section{Disclosure of interest}

The authors declare that they have no competing interest.

\section{Acknowledgements}

Thanks are due to crew members and scientific personnel participating in the research cruises that supplied material for this publication. Sesilie F. Tverberg (Univ. of Bergen) is acknowledged for the two SEM micrographs of Arctic material of P. obpyramidalis. The Aage V. Jensen Foundation is acknowledged for providing the first author with excellent writing opportunities while visiting the villa in Imperia that is owned by the foundation. Lauréne Pécuchet, PhD student at DTU Aqua, is acknowledged for providing a first draft of the translation of the title and abstract. The constructive comments by J. R. Young and E. Malinverno are greatly appreciated. 
The work was supported by the NRC project MicroPolar (project number 225956/E10) through

M. Heldal, University of Bergen.

\section{References}

Manton, I., Sutherland, J., Oates, K., 1976. Arctic coccolithophorids: two species of Turrisphaera gen. nov. from West Greenland, Alaska and the Northwest Passage. Proceedings of the Royal Society London, Ser. B 194, 179-194.

Moestrup, Ø., Thomsen, H.A., 1980. Preparation of shadow-cast whole mounts. In: Gantt, E. (Ed.) Handbook of Phycological methods. Vol. III. Cambridge University Press, Cambridge, pp. 385-390.

Thomsen, H.A., 1980a. Turrisphaera polybotrys sp.nov. (Prymnesiophyceae) from West Greenland. Journal of the Marine Biological Association of the United Kingdom 60, 529-537.

Thomsen, H.A., 1980b. Two species of Trigonaspis gen. nov. (Prymnesiophyceae) from West Greenland. Phycologia 19, 218-229.

Thomsen, H.A., 1980c. Quaternariella obscura gen. et sp.nov. (Prymnesiophyceae) from West Greenland. Phycologia 19, 260-265.

Thomsen, H.A., Buck, K.R., Coale, S.L., Garrison, D.L., Gowing, M.M., 1988. Nanoplanktonic coccolithophorids (Prymnesiophyceae, Haptophyceae) from the Weddell Sea, Antarctica. Nordic Journal of Botany 8, 419-436.

Thomsen, H.A., Egge, J.K., 2016. Papposphaera heldalii sp. nov. (Haptophyta, Papposphaeraceae) from Svalbard. Acta Protozoologica 55, 27-32.

Thomsen, H.A., Heldal, M., Østergaard, J.B., 2015a. Coccolithophores in polar waters: Papposphaera arctica HET and HOL revisited. Micropaleontology 61, 419-427. 
Thomsen, H.A., Heldal, M., Østergaard, J.B., 2015b. Coccolithophores in polar waters: Papposphaera sarion HET and HOL revisited. Micropaleontology 61, 429-438.

Thomsen, H.A., Oates, K., 1978. Balaniger balticus gen. et sp.nov. (Prymnesiophyceae) from Danish coastal waters. Journal of the Marine Biological Association of the United Kingdom 58, 773-779.

Thomsen, H.A., Østergaard, J.B., 2014a. Coccolithophorids in Polar Waters: Calciarcus spp. revisited. Acta Protozoologica 53, 145-157.

Thomsen, H. A., Østergaard, J. B., 2014b. Coccolithophorids in polar waters: Pappomonas spp. revisited. Acta Protozoologica 53, 235-256.

Thomsen, H. A., Østergaard, J. B., 2015. Cocolithophorids in polar waters: Trigonaspis spp. revisited. Acta Protozoologica 54, 85-96.

Thomsen, H.A., Østergaard, J.B., 2016. Papposphaera iugifera nov. sp. from West Greenland, Svalbard, and the Baltic Sea. Revue de Micropaléontologie 59, 71-79.

Thomsen, H.A., Østergaard, J.B., Hansen, L.E., 1991. Heteromorphic life histories in Arctic coccolithophorids (Prymnesiophyceae). Journal of Phycology 27, 634-642.

Thomsen, H.A., Østergaard, J.B., Heldal, M., 2013. Coccolithophorids in polar waters: Wigwamma spp. revisited. Acta Protozoologica 52, 237-256.

Thomsen, H.A., Østergaard, J.B., Heldal, M., 2016. Coccolithophores in polar waters: Papposphaera sagittifera HET and HOL revisited. Acta Protozoologica 55, 33-50.

Young, J.R., Bergen, J.A., Bown, P.R., Burnett, J.A., Fiorentino, A., Jordan, R.W., Kleijne, A., van Niel, B.E., Romein, A.J.T., von Salis, K., 1997. Guidelines for coccolith and calcareous nannofossil terminology. Palaeontology 40, 875-912. 
Young, J., Geisen, V., Cros, L., Kleijne, A., Sprengel, C., Probert, I., Østergaard, J., 2003. A guide to extant coccolithophorid taxonomy. Journal of Nannoplankton Research, Special Issue 1, 1132.

Young, J. R. Bown, P. R. Lees, J. A. (eds) Nannotax3 website. International Nannoplankton Association. 13 June 2015. URL: http://Coccolithophores/Coccolith families inc sed/Papposphaeraceae/Papposphaera/Papposphaera lepida

\section{Legends}

Fig 1. Collection sites. A. Map of the Weddell Sea, Antarctica, showing stations sampled during three cruises. Papposphaera obpyramidalis occurred at all three sites. B. Map of the Arctic Svalbard area showing the location of the single sampling site from where $P$. obpyramidalis has been observed.

Fig. 2. Papposphaera obpyramidalis TEM (Figs A-D, K) and LM (Figs E-J) / Antarctic material from the ANT X/3 cruise. A. Complete cell with curled up flagella and haptonema. B. Detail of proximal part of coccolith showing rim structure and central area calcification. C. High magnification of three differently sized coccoliths. D. Complete cell with curled up flagella and haptonema. E-J. Light micrographs showing different focal levels of the same cell; the haptonema and coccolith base outlines (arrows) are visible in Figs E, I. The scale bar (Fig. 2F) applies to all light micrographs. K. Reversed print of coccoliths showing unmineralized scales from the underlayer (arrows). 
312 Fig. 3. Papposphaera obpyramidalis TEM (Figs A-B / Antarctic material from the Ant X/3 cruise)

313 and SEM (Figs C-D / Arctic material from \#D2). A. Detail from Fig. B showing the haptonema. B.

314 Complete cell with partly extended flagella and haptonema. C. Complete coccosphere. D. High

315 magnification of coccoliths.

316

317

318 Table 1: Collection specific details pertinent to material selected here to illustrate $P$. obpyramidalis. 


\begin{tabular}{cccccc}
\hline Cruise & Station & Date & \multicolumn{2}{c}{ Position } & Depth (m) \\
\hline \hline ANT X/3 & $\# 21 / 355$ & 12-apr-92 & $70^{\circ} 22.06 \mathrm{~S}$ & $7^{\circ} 19.95 \mathrm{~W}$ & 2 \\
ANT X/3 & $\# 21 / 426$ & 20 -apr-92 & $70^{\circ} 21.64 \mathrm{~S}$ & $9^{\circ} 44.6 \mathrm{~W}$ & $2+10$ \\
ANT X/3 & $\# 21 / 391$ & 16 -apr-92 & $70^{\circ} 21.64 \mathrm{~S}$ & $8^{\circ} 54.84 \mathrm{~W}$ & 15 \\
ANT X/3 & 100 & 09 -apr-92 & $70^{\circ} 30.5 \mathrm{~S}$ & $8^{\circ} 01.5 \mathrm{~W}$ & 10 \\
ANT X/3 & $\# 21 / 431$ & 21 -apr-92 & $70^{\circ} 59.3 \mathrm{~S}$ & $11^{\circ} 00.1 \mathrm{~W}$ & $2+10$ \\
ANT X/3 & $\# 21 / 458$ & 28 -apr-92 & $69^{\circ} 06.6 \mathrm{~S}$ & $12^{\circ} 03.6 \mathrm{~W}$ & 100 \\
\hline$\mu$ Polar & $\#$ D2 & 15 -nov-14 & $78^{\circ} 59.3 \mathrm{~N}$ & $3^{\circ} 03.2 \mathrm{E}$ & 2 and 20 \\
\hline
\end{tabular}

Table 1: Collection specific details pertinent to material selected here to illustrat $€$ 
Illustration

Fig. 2A

Fig. 2B

Fig. 2C

Fig. 2D, 2K

Fig. 2E-J

Fig. 3A-B

Fig. 3C-D

:P. obpyramidalis . 

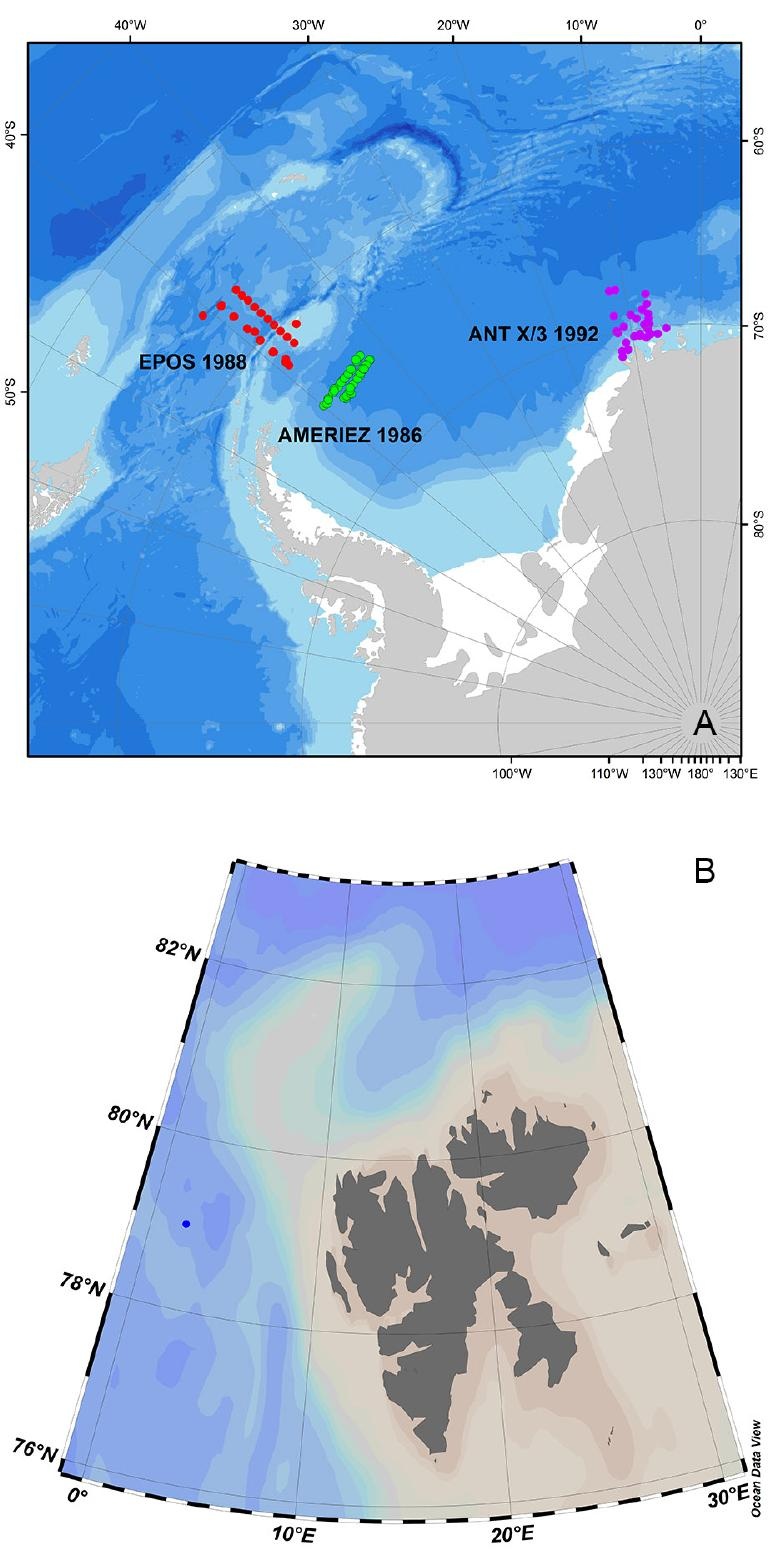
